\title{
Augustine as a Reader of His Christian Contemporaries
}

\author{
Michael Stuart Williams
}

\section{Introduction}

Augustine was not a great reader of his Christian contemporaries. That is to say, he seems not to have expended every energy (as might be expected of a modern scholar) in keeping up with the very latest to have been written on every topic on which he pronounced, or in which he could claim an interest. Part of the reason for this must be his relatively late conversion to Christianity. For as O'Donnell has pointed out, Augustine the professor of rhetoric - as he was by the time he reached his thirties - was inevitably better acquainted with the ancient Greek and Latin classics than he was with the far less sophisticated writings associated with Christianity (O'Donnell 2005a: 125). Indeed, his elliptical path to Christianity meant that the new convert was most familiar with the Christian Scriptures on account of their use by the Manicheans; and the contemporaries with whom he met to discuss ideas in Milan were more often Neoplatonists than Christians. Thus it seems clear that Augustine, unfamiliar with even the fundamental texts of his new religion, will have scarcely ventured into the writings of contemporary Christians.

It is possible that Augustine would have sought to fill this gap as he settled down to his new life as a Christian, but any ambitions in that direction were frustrated by his return to North Africa and the new responsibilities he took on for the church at Hippo. Even after his ordination as priest there, he was conscious of the need to catch up with his (Christian) reading, which at that stage seems to have meant the Scriptures themselves (Ep. 21.3). Moreover, had he wanted to read more widely, it is not clear that Hippo had much to offer. Copies of the gospels could be acquired in the town, or so Augustine implied; but he could also claim - perhaps with some hope of being believed - that even a text of Cicero was unobtainable (O'Donnell 2005a: 126; Ep. 118.9). Whether that was true or not, it seems unlikely that the latest writings of Latin theologians would be easy to find; and there was of course a further constraint on Augustine's reading in the fact of his inexpert Greek. We must therefore not imagine Augustine to have had a comprehensive grasp of the Christian literature we take for granted today.

A Companion to Augustine, First Edition. Edited by Mark Vessey.

(C) 2012 Blackwell Publishing Ltd. Published 2012 by Blackwell Publishing Ltd. 
Not all of this, however, should be put down to isolation or ignorance. For one thing, it must be remembered that argument by citation had not yet been established as the conventional Christian mode. For Augustine there was no established library of the "fathers of the church," and as yet no definite expectation that a Christian commentator should have read the works of his predecessors (O'Donnell 2005a: 125). Indeed, the requirement to engage with an established patristic canon was itself a fourth-century innovation, promoted to a large extent by Augustine's contemporary Jerome (see especially Vessey 1996, Rebillard 2000; also Williams 2006). Certainly Augustine was aware that important works had been written by his predecessors and by his contemporaries, and at times he would feel the need to excuse himself for having failed to read them. Thus in the preface to the third book of $\mathrm{On}$ the Trinity Augustine defended his decision to write a Latin treatise that neglected to engage with the major (Greek) authorities:

For sufficient accounts of these matters set out in Latin either do not exist or else cannot be found, or at any rate are difficult for us to find, whereas we are not so familiar with Greek as to be considered in any way capable of reading and understanding such things in those books; although from the few of these works which have been translated for us I have no doubt that they contain all that can usefully be discovered. [...] I should also confess that, by writing, I myself have learned much that I never knew before. (Trin. 3., prol. 1)

Important works on the Trinity had recently been written by Augustine's Greek contemporaries - Basil of Caesarea, Gregory of Nyssa, and Gregory of Nazianzus - in addition to the famous work by Athanasius (see Ch. 15 in this volume). Augustine pleads a lack of time and of ability to obtain, read, and fully understand these writings, and he admits that his own work may only repeat their insights. But some of this modesty is false; and we should also place some weight on his observation that writing a treatise is frequently a means of discovering or clarifying his own ideas.

For it was characteristic of Augustine to write "alone, under the spotlight" (O'Donnell 1991: 11), perhaps depending on his contemporaries but ultimately putting forth ideas of his own. It was not therefore only the inaccessible Greeks whose writings he ignored - the only Latin author cited by name in his work On the Trinity is Hilary of Poitiers (Madec 1999: 154). Even those Latin Christian authors whose works Augustine clearly admired not least the great North Africans, Cyprian and Tertullian - receive little close attention in his treatises. It is true that in controversy he was willing to show off his familiarity with these works, and to bring to bear, too, the wider Latin tradition, which included Lactantius and Hilary; and when challenged he was even prepared to struggle through the Greek works that were so frequently cited against him (Courcelle 1969). Outside of specific controversies, however, direct citations are rare, and they are often in the form of a convenient soundbite rather than a full and detailed discussion of a position (the evidence is collected in Bastiaensen 1987). The unexpected exception of Tyconius is perhaps to be explained by his doubtful status in the church as an ex-Donatist - so that here Augustine expressly acknowledges the source of his exegetical ideas partly in defence of Tyconius, and partly in order explicitly to delimit the extent of his indebtedness to this dubious source (see Edwards, Ch. 17 in this volume).

In general, however, Augustine prefers to make his own discoveries than to defer to the views of other authors, and this preference is consistent with a broader set of principles, which can be seen to center on the issue of authority. The fundamental point for Augustine was the authority of the Scripture, but from this developed an attitude to reading in 
general, to be applied regardless of the circumstances. It applied to the works of his Christian predecessors, to his contemporaries, and to his own writings. Reading was always a critical act, whether the text to be read was from the canonical Scriptures or was simply a letter from a friend.

\section{Authors and Authorities}

As bishop of Hippo, then, Augustine lived on the very edge of the empire, mixing for the most part only with his congregation and with the members of his monastic community. Even those friends who had accompanied him back to Africa were soon inaccessible: Alypius and Evodius had become bishops themselves, with duties and cares of their own; Nebridius had died, although even as his health was declining Augustine had found it impossible to visit him in Carthage (Ep. 10.1; for the parallel case of Severus see O'Donnell 2005a: 101-3). He was therefore largely cut off from the most prominent figures of his age; leaving aside the brief and memorable visit from Melania and Pinianus, very few of his own class and education were likely to find themselves passing through Hippo. Augustine's readings of his Christian contemporaries were thus largely mediated through correspondence; and it would not be too much to say that even his friendships were inescapably bounded by text. It is therefore worth looking closely at Augustine's more informal writing as a way to shed light on his subsequent ideas; and, in particular, we might pick out his correspondence with Jerome. Augustine's encounter with Jerome has been proposed as the source of much of the theory subsequently articulated in On Christian Teaching and in the Confessions (Vessey 1993); and it provides a rare example of Augustine interacting with a contemporary and engaging with both his "published" writings and his "private" letters.

It is not known for certain when Augustine first encountered Jerome's writings, or perhaps more importantly his reputation, but when he wrote his first letter in 394 or 395 he was able to imply some detailed knowledge of particular works. From the beginning it is apparent that he was aware of Jerome's project of translating the Old Testament into Latin, and he made explicit reference to his rendering of Job (Ep. 28: 2; he also discusses his translation of Jonah at Ep. 71.4-5). Later on he would mention the bibliographical work On Famous Men, which was apparently circulating in North Africa without its title (Ep. 40.2; see Vessey, Ch. 19 in this volume). It seems, however, that Augustine was most interested in Jerome's series of biblical commentaries: he had read enough to have noted their debt to Origen (Ep. 28.2), and his most significant query took up a passage in Jerome's commentary on Galatians (Ep. 28.3-4). The complexities of this scriptural debate have been well covered in a pair of recent studies (Hennings 1994; Fürst 1999), and the tale of the misfortunes and misunderstandings that beset the correspondence has also been told many times (there are accessible accounts in O'Connell 1979 and White 1990, and the story also features in Burrus 1999). The most important recent work has focused on the role of this encounter in the establishment of new models and norms of Christian letter-writing (thus Ebbeler 2001, developed in Ebbeler 2007 and 2009). Yet the exchange also reveals a consistent approach to the question of reading in general, and it is worth exploring further the implications of Augustine's attitude here.

To begin with, the dispute over Galatians amounts to a question of critical reading, in which Augustine bases his position on the truthfulness of the apostle Paul and on the absolute reliability of the canonical Scriptures. Jerome's mistake when he comes to argue 
an alternative case is to begin - albeit as a preliminary to a fuller discussion - by setting out a list of scholarly authorities on whom he was basing his view (Ep. 75.4). Augustine is required to confess that he is unfamiliar with some of the works Jerome cites, although he can name Cyprian and Ambrose in support of his own position; and, to show that he is not to be outdone in this fashion, he points out that a number of Jerome's own authorities have since been condemned as heretical, or at the very least unreliable (Ep. 82.23-4). But this is a contest Augustine is unlikely to win - indeed, his precarious grasp of the contemporary scholarship is betrayed by the fact that this "Ambrose" was in reality the impostor Ambrosiaster (see Ch. 15 in this volume), while Augustine's restricted access even to Ambrosiaster is evident from his citation of the same set of Pauline commentaries elsewhere under the name of Hilary of Poitiers (Bastiaensen 1987: 27-30; Lunn-Rockliffe 2007: 17-19). Augustine's library was thus apparently disorganized and his reading at times haphazard, but this would prove no insurmountable problem.

On the contrary, it could be turned into a virtue. Augustine's real concern in his response to Jerome is in fact to undermine the very principle of argument from (scholarly) authority. For one thing, Jerome had rashly claimed that he would be willing to err alongside the commentators he had cited, and Augustine duly makes fun of the assertion, feigning astonishment that anyone might be willing to be in error, however exalted the company (Ep. 82.23). The point is that authorities can always be wrong, with the sole exception of the Scripture, and that all Jerome's learned citations are therefore irrelevant to the real debate. Ultimately, the precise point at issue in Galatians became something of a sideshow: what was really at stake was the problem of how to read the Scriptures and how to argue about them.

For Augustine, the authority of the canonical Scriptures was the overriding concern. Once he had accepted that authority (a development he relates in Conf. 6.7-8), it brought with it a series of further commitments and, not least, an understanding of the Scriptures as qualitatively different from other forms of writing. The events recorded in the Bible were intrinsically authoritative, but the special status of the Bible depended on the divine inspiration granted to the scriptural authors themselves (Markus 1988: 14-15). Since no modern author could be believed to have been inspired in the same way, any authority that might be claimed on their behalf was always open to question (O'Donnell 1991: 24). Any writings outside the canonical Scriptures had therefore to be treated with some measure of skepticism and were to be regarded as necessarily provisional and incomplete. Thus, although the Scriptures could be read and studied in similar ways to non-biblical writings, and might even lead to similar conclusions, there was a real difference in the level of trust that could be placed in the texts and in their authors (Civ. Dei 1l.1, with Vessey and Pollmann 1999: 8, 21). For Augustine, the authorities cited by Jerome were not only inferior to the canonical Scriptures but fundamentally different in kind (Madec 1999: 152; the point is also discussed in Lütcke 1968: 111, 114-16).

Furthermore, Jerome's own authority as an interpreter of the Scriptures could not be taken for granted, and Augustine considered himself quite entitled to question it:

For I admit to Your Charity, I learned to show this reverence and respect only to those books of the scriptures that are now called canonical so that I most firmly believe that none of their authors erred in writing anything [...]. I, however, read other authors in such a way that, no matter how much they excel in holiness and learning, I do not suppose that something is true by reason of the fact that they thought so, but because they were able to convince me either through those canonical authors or by plausible reason that it does not depart from the truth. 
Nor do I think that you, my brother, hold anything else. In fact, I say, I do not think that you want your books to be read like those of the prophets or apostles, for with regard to their writings it is wicked to doubt that they are free from all error. (Ep. 82.3; trans. Teske 2001-5, here and passim)

By the time of this letter - around 405 - Augustine was firmly committed to this position, which he had consistently articulated in his writings since the Confessions (Williams 2008: 204-22). Given this set of theoretical commitments, Jerome's attempt to belittle Augustine's criticism with the barb that "everyone abounds in his own opinion" (Ep. 68.2) was always likely to backfire. Augustine would simply have agreed: he genuinely believed that neither Jerome nor himself had any intrinsic authority as interpreters of the Scriptures. For him the Scriptures were the only authority, and every interpreter was equally amateur.

It is therefore not difficult to see why Jerome might have objected to Augustine's approach in these unsolicited letters and might have seen them as an unprovoked attack on his reputation. By the time the letters arrived, Jerome was embroiled in the Origenist controversy, and Augustine's inquiry was at best ill-timed. We must not forget either - as Jerome certainly did not - that, for the majority of the correspondence, Augustine was a bishop, while he himself remained only a priest (Ep. 72.2-3; O'Donnell 1991: 14; Williams 2006: 198-9). From the beginning Jerome understands the discussion as a contest and cites the example of Dares and Entellus, among others, to warn Augustine that his zeal might backfire (Epp. 68.2, 72.3). In fact Jerome seems to have underestimated quite how serious Augustine was when it came to establishing the proper way to interpret the Scriptures. For him, this kind of debate was not to be reduced to a sporting contest: "You ask $[. .$.$] that we playfully exercise on the field of the Scriptures without causing$ injury to one another. As far as I am concerned, I prefer to do this seriously rather than playfully" (Ep. 82.2-3).

In this context, initiating a correspondence required a certain level of tact, and, throughout the exchange with Jerome, Augustine did his best to emphasize that his intentions were entirely honorable. He denied having written a treatise against Jerome, admitting only to a letter that had been circulated without his knowledge: "Nor did I send this letter to Rome, but to you, and I did not think it was against you, because I knew I had written it out of the sincerity of friendship, either to correct you or be corrected by you" (Ep. 82.33). Even so, there is a suspicion of arrogance in Augustine's insistence, from the start, that he is fit to dispute with Jerome. That Jerome was (slightly) older and a far more eminent figure must have made Augustine's insistence on speaking as an equal all the more impudent, not to mention imprudent (Ebbeler 2007; O'Donnell 2005a: 92). Nevertheless, his persistence in pressing for an answer even after Jerome has proposed a truce should not mislead us into imagining that Augustine was either naïve or, on the other hand, disingenuous. He was instead sure of himself, confident that his point was worth making and that he remained fully entitled to make it. Augustine had no intention of deferring, not even to a scholar so justly eminent as Jerome, but instead expected a recognition on both sides that error was a constant possibility. This may have been impertinent, insufferable even; and Augustine was no doubt wholly conscious of the reaction he was likely to elicit. But, to the extent that his questions deserved a reply, such an approach had some justification. After all, Augustine was surely correct to interpret Jerome's invitation to play nice as a last-ditch attempt to save face. In effect, he was being asked "to argue with a more learned friend with such an attitude that we necessarily 
approve of whatever he says and are not permitted to oppose him even a little for the sake of investigating the matter further" (Ep. 82.2). This, too, was insufferable: as he had already pointed out (not without a sharp note of sarcasm), "it might just possibly be the case that what you think is not the same as what the truth is" (Ep. 73.3; trans. Brown 2000: 272).

\section{Critical Readings}

Augustine thus justified his approach in this ill-tempered exchange with Jerome in part through his understanding of the authority of the Scriptures, in the light of which all human claims to authority were insignificant. At the same time, however, he also appealed to an ideology of friendship. Looking back on the correspondence, and seeking to excuse his apparent incivility, Augustine argued that he had in fact been behaving in a friendly fashion all along - as long as friendship were understood, as it frequently was in antiquity, as a relationship founded on absolute frankness and sincerity (Konstan 1996; see also Ebbeler 2009 and Rebenich, Ch. 27 in this volume). Whether or not Augustine was sincere when he advocated sincerity is an unanswerable question, and it must be admitted that a commitment to frank and open discussion allowed the inexperienced Augustine to demand answers from an older and more distinguished scholar and to claim the moral high ground in the process (Burrus 1999: 94). But an ideology can be both convenient and genuine, and it is clear enough at least that Augustine was consistent in preferring this approach. Thus his opening letter to Jerome had room for only a few prefatory remarks and those mostly concerned with the virtues of Alypius and of the letter-carrier Profuturus - before launching directly into unrestrained debate.

Augustine was aware that this abruptness might be offputting: in the very first paragraph of this letter he explicitly concedes that this will not be "the type of letter one usually writes" (Ep. 28.1). And certainly Jerome was moved to complain that, in criticizing his writings and inviting him to recant, Augustine was plainly seen to "do injury to our friendship [...] [and] violate the laws of our relationship" (Ep. 72.4). Jerome therefore counters with what was perhaps a more conventional definition, in which friendship means placing harmony above contention and avoiding any unnecessary unpleasantness (as in Ep. 68.3: "See how much I love you in that, not even after being provoked, do I want to reply, nor do I believe that the fault is yours"). This, of course, is no less self-serving, and to some extent the underlying theme is the negotiation of relative status (as brought out in Ebbeler 2007: 319). But this cannot be the whole story. Jerome ultimately concedes that Augustine is to be treated as an equal: "Let there be between us sincere brotherhood, and from now on let us send each other letters filled, not with questions, but with love" (Ep. 81). This recognition of his status, however, does nothing to change Augustine's position. He had not, after all, sought billets doux from Jerome, but specific answers to specific questions; he claimed still to be mystified that Jerome could ever have taken offence at his initial inquiry, to the point of considering giving deliberate offence in return; and he demonstrated the point by being conspicuously more welcoming to Jerome's belated and notably brusque reply on the particular issues at stake (Ep. 73.1-3).

Even after his apparent rhetorical victory, then, Augustine continued to press his point. He had hoped for friendship with Jerome in accordance with his own preferred understanding of the relationship - as one in which to tolerate an error or to remain silent about a disagreement is far more offensive than to point it out. A rebuke from a friend, he insists, will be salutary, though it may at first be painful to the ego: for "it is better that the swelling 
of the head hurt while it is cured than that it not be healed when it is spared" (Ep. 73.4). Augustine's model of friendship, then - whether in person or by letter - required an absolute openness to criticism. And this was far from being strictly one-sided. In his letters he repeatedly invited Jerome to criticize or correct him where necessary, and in the process he turned Jerome's own earlier accusation around:

I want all to do with regard to me what I have done with regard to you, namely, that whatever they find in my writing that is blameworthy they neither hide in a deceitful heart nor criticize in front of others, while they are silent before me. For I think that this rather does injury to our friendship and violates the rules of our relationship. (Ep. 82.31)

Jerome never took up this invitation, but the latter is not to be dismissed as nothing more than a display of conventional modesty. Augustine was displaying his commitment to a radical understanding of the rights and duties of friendship, which made little concession to the more conventional concern for epistolary decorum (Ebbeler 2009: 276). This was, moreover, an approach to reading consistent with Augustine's exegetical theory and practice; and one he can be seen to have applied throughout his readings of his Christian contemporaries.

Certainly he expresses the same concerns in his correspondence with Paulinus of Nola. This exchange of letters was pursued in parallel with Augustine's more rancorous exchange with Jerome - with whom Paulinus was also a correspondent - but had begun rather differently, apparently as the result of a connection cultivated by Alypius (Epp. 24, 25.1, 5). Paulinus was a celebrated figure in the western church, not for his writings so much as for his background as a Roman aristocrat and for his decision to embrace a life of asceticism (for which see Trout 1999a). His significance is clear in the eagerness of his Christian contemporaries - including Augustine - to claim him as a personal friend: Paulinus noster (Conybeare 2000: 1-2). Paulinus was a born diplomat, however, and knew how to open an exchange of letters: with extravagant praise and protestations of devotion, and the confidence that Augustine is already "known to my heart through your writings" and that "we know one another, though we are strangers" (Epp. 25.1, 30.2). The contrast with Augustine's opening letter to Jerome could hardly be more marked. Where Augustine was determined to get down to business, Paulinus is enthusiastic and effusive:

You see, my admirable brother, with whom I am one in heart, who are to be loved in Christ the Lord, how I acknowledge you as a friend, with what great awe I admire you, with what great love I embrace you, I who daily enjoy the conversation of your writings and am fed by the spirit of your mouth. For I would be right to call your mouth a pipe of living water and a vein of eternal truth because Christ has become a fountain of living water springing up in you unto eternal life. (Ep. 25.2; see also Vessey 1993: 186-8)

The relationship went on to develop far more smoothly than had Augustine's with Jerome. It would soon become a model of Christian epistolary friendship, as Paulinus and Augustine very publicly "learned how to cap each other's quotations from scripture, to defer and pontificate simultaneously" (O’Donnell 2005a: 97).

In thus characterizing the relationship, O'Donnell could not resist adding a sly parenthesis to the effect that Paulinus took note that Augustine "was better at being deferred to than at deferring" (O'Donnell 2005a: 97). And in some ways Paulinus does remain the junior partner: although better known than Augustine at the start of their 
relationship, he would not become a bishop for some time; and, although a living example of ascetic renunciation, he was certainly no theologian (Conybeare 2000: 14). The point should also be made that Paulinus was less concerned with his own authority and orthodoxy than was Jerome and was therefore less determined to define and defend his beliefs and positions against those of Augustine (pp. 43-4). Nevertheless, Augustine is most willing to correct Paulinus where the latter seems to show undue deference. In his response to Paulinus' opening letter he offers similarly extravagant praise of his correspondent, but notably warns him not to sacrifice a concern for the truth in his desire for friendship. Augustine first does this obliquely, with a warning not to trust the enthusiasm of his friend, the letter-carrier Romanianus: "for I have also noticed that he is often misguided in his judgments [...] out of his propensity to love" (Ep. 27.4). But he soon makes the point directly, in relation to the books he is sending Paulinus:

But when you read them, my holy Paulinus, do not let those things that the [divine] truth speaks through our weakness hold you so rapt that you are less careful to notice what I myself say. [...] For in these points that you rightly find displeasing, if you pay attention, you see me myself, but in those points in my books that you rightly find pleasing [...] you should love and praise him, with whom there is the fountain of life and in whose light we shall see the light [...]. (Ep. 27.4)

This is a plea to Paulinus not to abandon his critical acumen as a reader, thereby neglecting his duty, as a friend (and as a Christian), to correct Augustine's mistakes (Vessey 1993: 188-9).

That Augustine was willing to issue such a reminder goes to show how much importance he placed on his model of Christian friendship as requiring critical engagement (Ebbeler 2009). He would not leave uncorrected, even in such a prominent and sympathetic figure, the kind of flattery on show in Paulinus' previous letter to Alypius: "We admire and esteem [Augustine's body of work against the Manicheans] so much that we believe its words were dictated by God" (Ep. 24.2). The tone is less sharp, but the message is the same as in his correspondence with Jerome. Augustine would not allow his own authority, or anyone else's, to be overstated, and he would not allow modern authorities to supplant the authority of the Scriptures. The result is a consistent emphasis, throughout his writings, on their own provisional nature. This can arguably be recognized, soon after Augustine's conversion, in the dialogues from Cassiciacum - indeed, in the very choice of the open-ended dialogue form itself (Conybeare 2006: 40; see also Fuhrer, Ch. 21 in this volume). Letters, of course, were similarly open-ended and informal, and might well be regarded by their authors as provisional and incomplete. But the same concern can be seen to run through Augustine's major works, from the Confessions to the City of God, and especially in the works of his late career (Vessey 1998; Williams 2008: 213-22).

Perhaps the most obvious manifestation of this attitude is in the dogged auto-critique of the Retractationes (Reconsiderations). That work is a masterpiece of critical reading, in which Augustine can exploit to the full his understanding of friendship. There is no risk of giving offence to the author whose works he reads and rewrites, and scarcely any risk of offending anyone else, "nor will anyone but the obtuse dare to criticize me for criticizing my own errors" (Retr. prol. 1). As author and reader combined, Augustine could set about the task of reading and criticizing his own works in a manner in which Jerome and Paulinus, for very different reasons, had been reluctant to do it. Indeed, frustration at the unwillingness 
or inability of others to do this seems to have led to his initial decision to write the Reconsiderations - or so his first mention of the project (in a letter to the imperial official Marcellinus) would seem to suggest (Ep. 143.2). Here again he expresses the view that friends should criticize errors wherever they find them, and that correction should be received with gratitude; and he mildly rebukes Marcellinus in case he should think "that I am so great a man that in your opinion I would never have erred in my writings" (Ep. 143.3). The purpose of the Reconsiderations, therefore, is to supply the kind of criticism he has not received and to take back things he wishes he had not said. For "it is not true that I say no words or say only a few that I would want to take back if I could, as certain very dear friends of mine think, but rather more words than perhaps even my critics think" (Ep. 143.4).

It is certainly possible to be skeptical regarding Augustine's real interest in pointing out his own errors, and even to see the Reconsiderations as an atttempt to maintain control over the reception of his earlier works (O'Donnell 1992: 1.1;2005a: 317-19). But it is notable that, even when he makes these revisions, he does not claim any final authority. Augustine offers his own judgment on his writings, in anticipation of the final judgment of God; but he does not seek to assert his own earthly authority over the readers of the treatise, who are left to shift for themselves: "let each accept what I am doing however he wishes" (Retr. prol. 2; cf. Vessey 1998: 266). Even with regard to the Confessions he was willing to let readers make up their own minds:

The thirteen books of my Confessions praise the good and just God for whatever is good and bad in me, and encourage humanity's understanding and love for him; at least, it seems to me that they did this for me as I wrote them, and they do so again as I read them. What others feel about them they must see for themselves. (Retr. 2.6.1)

As Augustine had emphasized in an earlier letter to Marcellinus, the defence of one's own authority was very much a secondary concern in comparison with defending the authority of the Scriptures (Ep. 143.2). This point is reiterated soon afterwards, in Augustine's treatise On Seeing God, which itself takes the form of a letter to the aristocratic Paulina, and in which he takes great pains to cite the views of his Christian predecessors and contemporaries - including Jerome, and especially Ambrose (Ep. 147). He comes down in favor of Ambrose's opinions, but is nevertheless at pains throughout to define further the basis on which Paulina should make her own decision. "After all," he points out, "you do not believe me in the same way you believe Ambrose, from whose books I cited those valuable testimonies. Or if you think that you should believe both of us as having equal weight, will you in any way compare us to the gospel or set our writings on a par with the canonical Scriptures?” (Ep. 147.39). This was only to repeat the point Augustine had made at the beginning of the letter:

I do not want you to follow my authority so as to think that you have to believe something because I said it. Rather, either believe the canonical Scriptures if there is something that you do not as yet see is true, or believe the truth, which teaches inside you in order that you may see this clearly. (Ep. 147.2; Conybeare 2005: 65-6)

That Augustine is here writing to a woman might raise the suspicion that he is in fact protesting too much - that his disclaiming of personal authority is the best way to disarm less scrupulous claimants to authority, to whose arguments a woman might be thought 
particularly vulnerable (Vessey 2005b: $85-7$ ). And yet Augustine is quite prepared to make precisely the same points to a male reader over precisely the same issue. The very next letter in the collection was written to Fortunatianus of Sicca and serves both to supplement the letter to Paulina and to defend the positions taken up therein. Once again, Augustine cites the most relevant authorities, and once again he urges that their views, like his own, are always open to question:

After all, we ought not to regard the writings of any people, though catholic and highly praised, as being on a par with the canonical scriptures, so that we are not permitted - always preserving the respect owed to these men - to criticize and reject something in their writings if we should perhaps find something that they held other than is found in the truth, when understood with the help of God by ourselves or by others. That is the way I am with the writings of others; that is the way I want my readers to be. (Ep. 148.15)

\section{Textual Communities}

Augustine thus invited critical readings of his own work as much as he applied his own critiques to the works of others. All this, of course, he anticipated as being carried out in a context of friendship and "brotherly love" (Ep. 148.15). His awkward correspondence with Jerome might have given him pause in this respect, and certainly one aspect of it seems to have affected him greatly. This was the precedent of Jerome's recent vicious attacks on his former friend Rufinus - attacks that Jerome had sent Augustine for the sake of information, but perhaps also as an unsubtle hint; and, again, his response is revealing. $\mathrm{He}$ seems horrified that such a schism could have arisen as the result of intellectual disagreement among fellow students of the Scriptures:

I am [...] stabbed with the sharpest swords of pain when I think that there developed the damage of such great bitterness between you, to whom God had granted so generously and extensively that very thing that the two of you longed for, namely that you might, as the closest of friends savour together the honey of the scriptures! When, where, and for whom must we not fear, since this was able to happen to you [...]? (Ep.73.8)

Augustine later specifies that he is by no means blaming Jerome for the rift; he is mourning instead the impermanence of friendship (Ep. 82.1). But it is interesting that some manuscripts of his first response read not "the two of you" (vestrum) but "the two of us" (nostrum): whether this was in the original or was a subsequent correction, it seems nonetheless psychologically plausible. It is not unlikely that Augustine was indeed thinking of himself in this passage, both in his relationship with Jerome and in his other Christian friendships.

The prospect of studying the Scriptures among friends was indeed Augustine's ideal. It was to have been the purpose of the ascetic community he had planned to establish in North Africa (Ep. 21.3), and its character could to some extent be recaptured even in an exchange of letters. Thus, when he writes to Nebridius in some of his earliest letters, he figures the correspondence as a conversation, imagining the presence of his friend and writing as though they were engaged face to face in debate (Ep. 3; Stock 1996: 128). Later on in his episcopal career Augustine is less able to indulge in these rhetorical flights; but something of the same effect is visible in his correspondence with Paulinus of Nola, which is increasingly dominated by intensive discussion on the interpretation of the Scriptures (Epp. 121,149; Trout 1999a: 203). Paulinus can be seen to have thrown himself 
wholeheartedly into such a textual relationship; and if Augustine still sometimes hankers after the physical presence of his friend, it is for the most part confined to those matters in which, for example, the precise tone of voice is at stake (Ep. 149.23; cf. Conybeare 2000: 134-5). Similarly, Paulinus has been credited with inspiring Augustine with his vision of "the unanimity of Christians in Christ" (Conybeare 2000: 145); but Augustine could offer in return his own model of collaboration in the face of the Scriptures.

Thus, by the time he came to write the Confessions, Augustine envisaged the act of reading and interpreting the Scriptures "as the combined work of two or more human beings in the presence of God [...] in the spirit of charity" (Vessey 1993: 211). In contrast to some contemporary writers, he did not seek to restrict this collaboration to a physical, ascetic community: instead, the emphasis is on the caritas that creates a community between author and reader and that could be extended between readers of the same canonical texts (Vessey 1993: 194-5; Stock 1996: 211). It was the rules of this kind of interpretation that Augustine had set out to define in On Christian Teaching, which offers an early glimpse of such a Christian "textual community" (Stock 1996: 196). Here already it was charity rather than authority that allowed access to the proper interpretation of the Scriptures: "[W] hen a person has understood that the purpose of the commandment is charity, which comes from a pure heart and a good conscience and a sincere faith [ 1 Tim. 1:5], and has based his whole understanding of the divine scriptures on these three, then he may safely proceed with the interpretation of these books" (Doc. chr. 1.40.44). And it was the presence and active involvement of friends in collaboration or "conference" that provided a check on the interpreter, allowing personal vanity to be set aside in pursuit of "the common truth of interpreting scripture" (Vessey 1993: 211; O’Donnell 1991: 19; see also Cameron, Ch. 14 in this volume).

The result is a model of reading in which every exponent is equally amateur, in which the Scriptures are the only reliable source of knowledge, and in which even the most advanced student can stand to be corrected by a colleague. The point is driven home through a list of biblical figures who received their knowledge from God, but who nevertheless submitted to human instruction:

For is it not true that God spoke with Moses, and yet with the greatest of foresight and an absence of pride he accepted advice on ruling and governing so great a people from his fatherin-law, who was even a foreigner? For he knew that good advice, from whomever it might come, should be credited not to him but to that immutable God who is truth itself. (Doc. chr. prol. 7; Vessey 1993: 192)

Men of faith might defer to one another regardless of experience or expertise, just as (on Augustine's reading) Paul had corrected Peter in Galatians, and just as - although the parallel is not made explicit - he was in turn correcting Jerome (Brown 2000: 450; Ebbeler 2001: 214-17).

Nevertheless, Augustine's ideal model of critical reading among friends was rarely possible to put into practice. He had seemed to concede, in response to the quarrel of Rufinus and Jerome, that a tactful silence might at times better serve the interests of the church (as noted in Burrus 1999: 94-5) - but this is clearly the preferred option only when true friendship and frankness have proven impossible. This indeed was the path ultimately followed in Augustine's own relationship with Jerome, who backed down after the initial skirmish: to subsequent questions he sent only polite excuses and unqualified approval (e.g. Ep. 172). Paulinus remained friendly but the letters dried up, as both he and Augustine took on more significant official responsibilities. And of Augustine's correspondents in 
Africa, very few could match his education and his eminence in the church. Thus for example, Quodvultdeus (the future bishop of Carthage) wrote to Augustine in 427 to ask him to compile a brief catalogue of all known heresies - something Augustine was reluctant to do (Ep.221.2). To the reply that two such works already existed in Greek, Quodvultdeus gave a few practical responses - that these were not sufficiently brief, or comprehensive, or up-to-date - but played up his own lack of education: "It is also useless to offer Greek eloquence to a man like me, who am not learned in Latin" (Ep. 223.2). Such a claim need not be taken at face value; but, as a rhetorical stance, it is revealing: Quodvultdeus is not interested in competing with Augustine, or even in presenting himself as an equal. $\mathrm{He}$ handles him instead with a combination of flattery and self-abasement, in effect positioning Augustine as patron to the African church (Ep. 223.3). In this way Augustine, rather despite himself, ended up an authority after all.

\section{Conclusion}

Augustine thus promoted and practiced a model of reading that made great demands on good will among friends; and the practical result was that very few of his contemporaries were prepared to engage in it with him. He could do little but demand in vain that his own works should receive a sympathetic but critical reading, while his own readings of the works of others too often erupted into controversy. But his model of Christian collaboration in the face of the Scriptures perhaps had significance still. We might see its results in a kind of collaborative reading that did not require explicit discussion in order to create a community around a text. Such a reading could be intimate, even tacit, with discussion giving way to silent communion in the light of the Scriptures: Vessey offers the example of the conversion of Augustine and Alypius in the Confessions, in which spoken communication was minimal and might indeed have been altogether absent (Conf. 8.12.30; Vessey 1993: 205-6). We might detect a similar flavor in the silent, intimate community created a little earlier in the Confessions, in which Augustine and others seeking spiritual advice are reluctant to interrupt Ambrose of Milan as the bishop silently reads (Conf. 6.3.3).

During his time in Milan, Augustine never quite managed to draw Ambrose into discussion of any lengthy or difficult matter, although in the Confessions he praises his sermons, and he will subsequently grant Ambrose's writings immense authority (Doc. chr . 4.21.46). But it may be that Augustine's reading of Ambrose was heavily influenced by this one scene, that the authority he granted to Ambrose did not depend entirely on his writings, but on his example as a reader. Thus, although he had initially come to Ambrose for advice, Augustine is surprisingly sympathetic to the bishop's absorption in his work. He offers in retrospect a reading of Ambrose he could not manage at the time: one that imagines "what hopes he nurtured, what struggles he faced against the temptations of his own exalted position, his consolations in adversity and the whole aspect he kept hidden" (Conf. 6.3.3). Ambrose's silence now reveals to Augustine a vivid inner life, and before he settles on the most prosaic explanation for this silence - that the bishop needed to rest to preserve his voice - he offers some revealing speculations. Perhaps, he suggests, Ambrose was seizing a rare opportunity to catch up on essential reading; or perhaps he was refusing to read aloud so that he would not be distracted by the need to explain a difficult passage.

What is common to both explanations is the character imputed to Ambrose by Augustine: specifically, his knowledge of his own limitations and his unwillingness to pose as an expert. Augustine does not doubt that Ambrose understood what he read, but 
he has him refusing to show off his expertise. This is a portrait of Ambrose, then, as Augustine's ideal reader. He makes no claim to authority but subordinates his own personality to the Scriptures. Ambrose was a reader among readers - and Augustine adopted this approach as his own. For Augustine, then, nothing was to be definitively stated, and everything might be taken back. This was a truth he would later rediscover and restate in the prologue to his Reconsiderations: writers are encouraged to say many things, but the wise man is silent before the Scriptures. This was something he had learned years before, in his reading (and rewriting) of his great contemporary.

\section{Further Reading}

Anyone interested in exploring further Augustine's engagement with his Christian contemporaries might begin with some studies of his attitude to his predecessors: Bastiaensen 1987 and Courcelle 1969 discuss Latin and Greek influences respectively, Madec 1999 his Christian predecessors in general. Information on Augustine's relationships with specific contemporaries can be sought in $A L$ and $A T A$; the former also includes indispensable contributions by Lütcke ("Auctoritas") and Divjak ("Epistulae"). Lütcke 1968 remains the fullest account of the role of authority in Augustine's thought and writings. For a more personalized and less systematic approach, one place to start would be with an alternative retractatio: the comment of Peter Brown, in the revised edition of his groundbreaking biography, that, in the light of new evidence, "I have found [Augustine] [...] to be considerably less the authoritarian, stern figure that my reading of the evidence available to me in the 1960s had led me to suspect" (Brown 2000: 445). This image of a less inflexible and dogmatic Augustine also provided the starting point for Conybeare 2006, which is mostly concerned with the early dialogues; and it is raised in direct relation to his letter-writing in the discussion between Conybeare 2005 and Vessey 2005b. It should come as no surprise to discover that this aspect of Augustine had already been adumbrated in O'Donnell 1991 and is explored further (with perhaps a stronger dose of cynicism) in O'Donnell 2005a. These pieces are particularly valuable in their willingness to see Augustine engaged in the give-and-take of ordinary social relations; a similarly hardheaded approach, applied to the correspondence with Jerome, may be found in Ebbeler 2007 and 2009; and see now further Ebbeler 2011. Augustine's strategies as a reader are considered in detail as a response to his encounters with Jerome and Paulinus in Vessey 1993, where Augustine's preference for conference and colloquy is made very clear. More elaborate accounts of Augustine's theory and practice of reading may be found in Markus 1996 and Stock 1996, both of whom focus on his reading of the Scriptures, and in Pollmann and Vessey 2005, on his engagement with the classical disciplines. Augustine's use of citations in particular is the focus of Rebillard 2000, and his commitment to a kind of incompleteness is explored in Vessey 1998. Finally, some (but not all) of Augustine's contemporaries have been well served with recent studies: for Jerome, the classic account of Kelly 1975 has now been revised and supplemented by Rebenich 2002 and Williams 2006; for Paulinus of Nola, there is an excellent biography in Trout 1999a, while Conybeare 2000 and Mratschek 2002 give full weight to the letters and their social contexts. Ambrose of Milan's distant relationship with Augustine is covered best in McLynn 1994, while specific borrowings are explored in Cipriani 1997a; the significance of Ambrosiaster is rightly emphasized in Lunn-Rockliffe 2007. All of these authors, along with Augustine himself and many besides, are chaptered in Young, Ayres, and Louth 2004. 